\title{
ACCESS TO FORMAL CREDIT FACILITIES AMONG SMALLSCALE CROP FARMERS' IN GWAGWALADA AREA COUNCIL, ABUJA, NIGERIA
}

\author{
Olugbenga Omotayo Alabi, PhD \\ Department of Agricultural-Economics and Extension, Faculty of Agriculture, \\ University of Abuja, Nigeria \\ E-mail: omotayoalabi@yahoo.com \\ Alimi Folorunsho Lawal, PhD \\ Department of Agricultural-Economics and Extension Services, \\ Faculty of Agriculture, Ibrahim Badamasi Babangida University Lapai,Niger State, Nigeria \\ E-mail: funsolawal@yahoo.co.uk \\ Henry Onyebuchi Chiogor \\ Department of Agricultural-Economics and Extension, Faculty of Agriculture, \\ University of Abuja, Nigeria \\ E-mail: chiogorhenry@yahoo.com
}

\begin{abstract}
This study examined access to formal credit facilities among small scale crop farmers in Gwagwalada Area Council, Abuja, Nigeria. The specific objectives of this research were to: identify the socio-economic characteristics of sampled small scale crop farmers in the study area; examine sources and accessibility of credit to the sampled small scale crop farmers in the study area, evaluate factors influencing accessibility of credit among the sampled small scale crop farmers in the study area and identify problems encountered by farmers in accessing credit. Primary data were used for the study. Systemic random sampling technique was adopted; one hundred (100) respondents were selected. The data were collected and analysed using descriptive statistics and Logit Regression Model (LRM). The study showed that eighty seven (87) percent of the sampled small scale crop farmers were male. About eighty six (86) percent of the respondents had their age range from 30-60 years. Eighty three (83) percent of the respondents were married. Furthermore, eighty one (81) percent had formal education. The study further showed that thirty one; (31) percent of farmers obtained credit facilities from banks. The result of Logit regression model showed that farm size, membership of co-operative and household distance from source of credit had significant positive influence on access to formal agricultural credit among the respondents in the study area at $\mathrm{P}<0.05 ; \mathrm{P}<0.01$; and $\mathrm{P}<0.01$ levels respectively. Delay in approval and disbursement of credit, lack of collateral security as well as too much bank procedures and requirements constituted the major constraints in accessing formal agricultural credit among the respondents in the sample area. The study recommends that credit should be disbursed to farmers with minimum delay; formal credit institutions should be widely spread and situated in places close to farmers. Also farmers should be encouraged by relevant government agencies to seek ways of increasing their farm size and rural farmers should be encouraged to join co-operative associations as this can increase their chances of accessing formal agricultural credit facilities.
\end{abstract}

\section{KEY WORDS}

Formal credit, Logit model, Smallscale farmers.

The decline in the Nigerian economy particularly in the area of productivity has often been blamed on lack of credit facilities which prevents farmers from adopting improved practices, since some of them lack the collateral needed to secure loan or credit from financial institution. It has also been argued that when agricultural credits are made accessible to farmers it will go a long way in breaking the cycle of poverty plaguing farmers 
liberating them to improve their adoption of modern farm technologies which could enhance productivity and farmers income (Adejobi and Atobatele, 2008). One of the factors attributed to the declining productivity of the sector is farmer's limited access to credit facilities (Nwaru ,2004, Mayong et al, 2005). Agricultural credit has been described as encompassing all loans and advances granted to borrowers to finance and service production related activities in agriculture such as, fisheries, forestry, distribution and marketing of products resulting from these activities (Okpetu, 2001). Thus, credit availability is one of the prerequisites for agricultural development as well as increased agricultural productivity. According to Alfred (2005) acquisition and utilization of credit for agricultural purposes promotes productivity and consequently improves food security status of a community.

Problem Statement. The critical role of credit in economic development cannot be over emphasized and research has established the existence of a positive relationship between agricultural development and availability of credit to farmers (Olaitan, 2006), credit institutions have over the years shy away from lending to small scale farmers who form the larger part of the farming population, citing reasons such as high default rate, difficulty in monitoring numerous individuals whose loans do not provide much returns on investment, as well as not being cost effective (Jumare, 2006). Access to credit plays a prominent role in developing strategies for the agricultural sector in Nigeria. This study intends to provide answers to the following research questions:-

(i) What are the socio-economic characteristics of sampled small scale crop farmers in Gwagwalada Area Council, Abuja, Nigeria?

(ii) What are the sources of agricultural credit to the sampled small scale crop farmers?

(iii) What are the factors influencing accessibility of formal agricultural credit among the sampled small scale crop farmers in the study area?

(iv) What are the problems encountered by sampled farmers and suggested solutions to constraints encountered in accessing agricultural credit?

Objectives of the Study. The broad objective of this study is to analyse factors influencing accessibility of formal credit facilities among small scale crop farmers' in Gwagwalada Area Council, Abuja. The specific objectives of the study are to;

(i) identify the socio-economic characteristics of sampled small scale crop farmers in Gwagwalada Area Council, Abuja, Nigeria.

(ii) examine sources and accessibility of agricultural credit to the sampled small scale crop farmers.

(iii) evaluate factors influencing accessibility of formal agricultural credit among the sampled small scale crop farmers in the study area.

(iv) identify problems encountered by sampled farmers and suggested solutions to constraints encountered in accessing agricultural credit?

Significance of the Study. In Nigeria only a few studies have been carried out to analyze various factors affecting accessibility to credit facilities among small scale farmers as well as quantify the effect credit has in stimulating agricultural output and productivity in order to provide a sound basis for a micro credit advocacy (Amadi et al, 2001, Omeje and Ajayi, 2009, and Afolabi, 2010). Researchers continue to analyze and better understand problems and issues in rural development in general, and the situation of small scale farmers in particular. It is critical to assess the characteristics of agricultural production strategies among small scale farmers in order to have a greater understanding of the factors affecting and determining access to credit. Empirical research has shown that borrowing constraints prevent small scale farmers in developing countries from adopting high-return innovations such as irrigation systems and modern varieties as well as purchasing modern farming implements (Blackman, 2001).

\section{LITERATURE REVIEW}

The concept of credit in agriculture has been known since the seventeenth century when peasants in China used rural credit in farm production to increase their cash income, and to improve their standard of living (Ming-Ji, 2004). Agricultural system are so diverse, 
based on farm size, location, crops being grown, socioeconomic background among many other factors (Odoemenem et al, 2001).According to (Ghorbani et al, 2005), credit is defined as the ability to obtain goods and services or money now in exchange for promise of payment in future. The provision of credit for small scale farmers in developing countries is centered on two main issues: the establishment of specialized agricultural credit institutions and the outreach of rural credit institutions. Specialized agricultural credit institutions (SACI) have existed for decades and their establishment was based on a political response from the government, which is highly supervised and controlled (Adams, 1992). The SACl's had many operational problems. Such as limited outreach of credit which was available to the wealthy and large farmers only, and a high dependence on subsidies from external donors. Thus, these institutions were unable to be sustained due to capital deficit and poor loan repayment (Yaron, 2002).Credit demand refers that an individual has chosen to borrow and has already borrowed (Tinh et al., 2010). But, this definition fails to include those who need credit but not applied (might be discouraged) and those applied already but constrained. Diagne (1999) defines demand for credit as: the borrowers' choice of the optimal loan amount. Demand for credit for our case follows from Balogun and Yusuf, (2011) and Chen et al, (2008) definition which states that demand for credit is the probability that an individual answered yes to the question "did you apply for credit before?" and it includes also those who are discouraged. To this end, different literatures investigate various factors that affect demand for micro credit by rural farm households (from formal and informal sources) (Beck, 2007; Okurut et al, 2004).

Types of Rural Credit. Two different types of credit, formal and informal, are accessed by small scale farmers. Some features of these credit types are discussed below.

Formal Financial Institutions. Formal financial institutions are organisations which are owned, controlled, licensed and registered or regulated by the government. These include the commercial banks, state-owned banks, agricultural development banks and rural banks (Martokoesoemo, 2004).

Informal Financial Institutions. Informal financial institutions operate without physical collateral, involve small loans and short-term transaction, and are characterized by adaptability and flexibility of operations in a certain area (Adams and Fichett, 2002; Ghate, 1988). Lower transaction costs provide a comparative advantage for informal financial institutions because of their small scale operations and speculations (ADB, 2009).

One of the principal characteristics of informal credit as stated by Okwoche et al, (2012), and Afolabi, (2010) is the higher interest rates imposed on loans relative to those by the formal banking sector. But this applies more to the informal credit institution (money lenders). Credit from cooperative societies generally attracts interest rates of less than 10 percent, while for some informal institutions such as rotating savings and credit associations (RoSCAs) no interest is charged. The average loan repayment rate is as high as 89.7 percent for Non-Governmental Organizations and Micro Finance Institutions (NGO-MFIs) (Okweche et al, 2012). However, loan default with respect to subsidized public credit from a formal institution like the Nigerian Agricultural and Co-operative Rural Development Bank (NACRDB) accessed by farmers in southwest Nigeria was 77 percent (Adejobi and Atobatele, 2008). It is asserted that most of the defaults arose from poor management procedures, loan diversion, and unwillingness on the part of some clients to repay loans (Olaitan, 2006). According to Etonihu, (2010) the lack of bank accounts, collateral, and information regarding the procedure for accessing credits from banks limit rural farmer's access to credit from formal institutions. Adejobi and Atobatele, (2008) suggested that loan default could limit access to credit, while Atieno, (2007) opined that the complex mechanism of commercial banking is least understood by the small and medium scale farmers, and thus, limits their access. Bolarinwa and Oyeyinka, (2005) blamed the limitation on imperfect and costly information problems encountered in the financial markets; credit rationing policy; and banks' perception of agricultural credit as a highly risky venture. 


\section{METHODOLOGY}

The Study Area. The research was carried out in Gwagwalada Area Council, Abuja. Gwagwalada is one of the six Area Councils that make up the Federal Capital Territory, it is located along Latitude $8^{0} 56^{\prime} 29^{\circ} \mathrm{N}$ and Longitude $7^{\circ} \mathrm{S}^{\prime} 31 \mathrm{E}$. The Council was created on the $15^{\text {th }}$ October, 1984. Its official population figure of one hundred and fifty thousand 150,000 people has since become obsolete. The relocation of the seat of government from Lagos to Abuja in 1992 and frequent demolition of illegal structures within the Federal City Center brought a massive influx of people into the Area Council being one of the fastest growing urban centers in the FCT. The population of the Area Council has grown to over one million $(1,000,000)$ people (FCTA Area Councils Services Secretariat (ACSS) report, (2012). The council is composed of 10 elected councilors representing the ten wards of the council, namely: Zuba, Ibwa, Dobi, Kutunku, Tunga Maje, Gwako, Paikon-kore, Ikwa, Quarters and Central. Gwagwalada falls within the savannah vegetation of West African Sub-region. The major inhabitants are the original settlers: namely, Gwari, Koro, Bassa, Gede and the Hausa Fulani, as well as the immigrant population of other Nigerians. Subsistence agriculture is the main economic activity of the populace and the major crops grown in the Area Council are sorghum, maize, yam, millet, cassava, rice, beniseed, etc.

Sampling Technique and Sample Size. A comprehensive list of three hundred (300) small scale crop farmers was obtained from Agricultural Development Project (ADP) area office in Gwagwalada, Abuja, Nigeria, which serve as the sampling frame. A systematic random sampling technique was adopted. A total sample size of One hundred (100) small scale crop farmers was used for this study. Ten (10) small scale farmers were selected from each of the ten (10) Council wards in Gwagwalada Area Council.

Method of Data Collection. Data for this study were obtained mainly from primary sources. Primary sources of information were obtained using a structured questionnaire. The questionnaire was designed to extract information on; socio-economic characteristics, these ranged from age, sex, farm size, farming experience, household size, level of education, marital status, annual farm investment, awareness of access to credit. This questionnaire was supported with direct interview where needed.

Method of Data Analysis. Data for the study were analyzed using both descriptive and Logit Regression Model (LRM). Objectives (i) and (ii) were analyzed using simple descriptive statistics such as mean, percentages and frequency distribution. Objective (iii) was accomplished using a Logit Regression Model (LRM).

Descriptive Statistics. This involved the use of the mean, standard deviation, percentages and frequency distribution to collate and analyse the data collected from the survey. This was used to achieve specific objectives (i) and (ii).

Logit Regression Model (LRM). In order to determine the factors influencing accessibility of credit among the sampled small scale crop farmers in the study area, the Binary Logistic Regression that was used is specified below:

$$
\begin{aligned}
\mathrm{P}_{i}=\mathrm{F}\left(Z_{i}\right) & =\frac{1}{1+\exp \left(-X_{i} \beta\right)} \\
Z_{i} & =X_{i} \beta
\end{aligned}
$$

Where, $\mathrm{P}_{i}=$ Probability that the ith farmers select the first alternative; $X_{i}=$ Vector of sampled farmers associated with the ith farmer; $e=$ represent the natural logarithmic base; In this equation $Z_{i}$ can range from positive infinity to negative infinity.

The probability $\left(\mathrm{P}_{i}\right)$ lies between 0 and 1 .

$$
Z_{i}=\log \left[\frac{P}{1-P}\right]=\log Y=\beta_{0}+\beta_{1} X_{1}+\beta_{2} X_{2}+\beta_{3} X_{3}+\beta_{4} X_{4}+\beta_{5} X_{5}+\beta_{6} X_{6}+\beta_{7} X_{7}+\beta_{8} X_{8}+\beta_{9} X_{9}+\beta_{10} X_{10}+\mu_{i}
$$

Where, $Z_{i}=$ Probability of Access to Agricultural Credit, Access $=1$; No access $=0$; $Y=$ Access to Credit (1, Access; 0 , Otherwise); $\beta_{s}^{\prime}=$ Regression Coefficients; $X_{1}=$ Age 
(Years); $X_{2}=$ Household Size (Units); $X_{3}=$ Level of Education (in Years). (Non-Formal $=2$; Primary $=6$; Secondary $=12$; Tertiary $=14) ; X_{4}=$ Farm Size (Hectares); $X_{5}=$ Annual Farm investment (Naira); $X_{6}=$ Membership of Co-operative (Member $=1$, Non-Member $=0$ ); $X_{7}=$ Access to Extension Services (Access $=1$, No Access $=0$ ); $X_{8}=$ Awareness of Availability of Credit Facilities (Aware $=1$, Not Aware $=0$ ); $X_{9}=$ Farming Experience (Years) $\mathrm{X}_{10}=$ Household Distance from Source of Credit (Kilometres); $\mu \mathrm{i}=$ Error Term.

\section{RESULTS AND DISCUSSION}

Socio-Economic Characteristics of Sampled Small Scale Crop Farmers. The results of socio-economic characteristics of the respondents are presented in Table 1 . The study showed that eighty seven (87) percent of the sampled small scale crop farmers were male, while, thirteen (13) percent were female. Thus, male gender dominates farming in the study area. The male dominance of this rural source of livelihood implies the laborious nature of farming operations right from tillage to harvesting which their female counterparts cannot easily undertake. This is because farming operations require a lot of energy and is labour intensive especially in the rural areas where crude farm implements are usually used. This agrees with the findings of (Olaleye, 2000).

Table 1 - Socio-Economic Characteristics of the Sampled Small Scale Crop Farmers in Gwagwalada Area Council, Abuja, Nigeria

\begin{tabular}{|c|c|c|}
\hline \multicolumn{3}{|c|}{ Frequency } \\
\hline \multicolumn{3}{|c|}{ rTequency } \\
\hline Male & 87 & 87.00 \\
\hline Female & 13 & 13.00 \\
\hline \multicolumn{3}{|l|}{ Age (Years) } \\
\hline $20-30$ & 08 & 08.00 \\
\hline $31-40$ & 25 & 25.00 \\
\hline $41-50$ & 36 & 36.00 \\
\hline $51-60$ & 25 & 25.00 \\
\hline $61-70$ & 06 & 06.00 \\
\hline \multicolumn{3}{|l|}{ Marital Status } \\
\hline Married & 83 & 83.00 \\
\hline Single & 10 & 10.00 \\
\hline Widow & 03 & 03.00 \\
\hline Divorced & 04 & 04.00 \\
\hline \multicolumn{3}{|l|}{ Level of Education (Years) } \\
\hline Primary & 41 & 41.00 \\
\hline Secondary & 31 & 31.00 \\
\hline Tertiary & 09 & 09.00 \\
\hline Non-Formal & 19 & 19.00 \\
\hline \multicolumn{3}{|l|}{ Household Size (Units) } \\
\hline $1-5$ & 41 & 41.00 \\
\hline $6-10$ & 48 & 48.00 \\
\hline $11-15$ & 11 & 11.00 \\
\hline \multicolumn{3}{|l|}{ Farm Size (Hectares) } \\
\hline$<1$ & 37 & 37.00 \\
\hline $1-5$ & 52 & 52.00 \\
\hline $6-10$ & 11 & 11.00 \\
\hline \multicolumn{3}{|l|}{ Main Source of Income } \\
\hline Farming & 90 & 90.00 \\
\hline Civil Servant & 03 & 03.00 \\
\hline Marketing & 03 & 03.00 \\
\hline Trading & 03 & 03.00 \\
\hline \multirow{2}{*}{\multicolumn{3}{|c|}{ Farming Experience(Years) }} \\
\hline & & \\
\hline $1-10$ & 13 & 13.00 \\
\hline $11-20$ & 24 & 24.00 \\
\hline $21-30$ & 28 & 28.00 \\
\hline$>30$ & 35 & 35.00 \\
\hline Total & 100 & 100.00 \\
\hline
\end{tabular}


Table 1 showed that eighty six (86) percent of the respondents had their age ranges between 30-60 years. The implication of this result is that farming in the area enjoys higher patronage by active matured people who are energetic enough to withstand the stress involved in farm operations. This result suggests that majority of peasant farmers in the study area are within the age bracket in which people are innovative and active at work (Asiabaka, 2008). Furthermore, eighty three (83) percent of the sampled small scale crop farmers were married; ten (10) percent were single. Also, eighty one (81) percent of the farmers had formal education, while nineteen (19) percent had non-formal education. This result suggests that the respondents were literate. About ninety-six (96) percent of respondents had less than 10 members as household size. The result is in line with the findings of Asogwa et al (2014) who opined that majority of small scale farmers have an abundant supply of family labour, which can be harnessed for increased agricultural production. The results further showed that ninety (90) percent of the respondents were mainly into farming. Majority of the farmers, fifty two (52) percent had less than 5 hectares of farmland. This suggests that the farmers were mostly small scale farmers.

Sources of Agricultural credit of Sampled Small Scale Crop Farmers. Table 2 shows that thirty one (31) percent of farmers obtained credit facilities from banks, Okwoche et al (2012) reported that loan from non-institutional sources are devoid of administrative delays and there is no insistence on collateral security. The low patronage of banks may be due to complicated procedures, delay in approval and disbursement, high administrative charge, high interest rate as well as lack of collateral among the sampled respondents (Ihomodo, 2005).

Table 2 - Sources of Agricultural Credit to Sampled Small Scale Crop Farmers

\begin{tabular}{|l|c|c|}
\hline \multicolumn{1}{|c|}{ Sources of Credit } & Frequency & Percentage \\
\hline (a) Informal Sources & 20 & 20.00 \\
(i) Friends & 30 & 30.00 \\
(ii) Relatives & 19 & 19.00 \\
(iii) Neighbours & 31 & 31.00 \\
(b) Formal Sources $\quad$ Total & $\mathbf{1 0 0}$ & $\mathbf{1 0 0 . 0 0}$ \\
\hline \multicolumn{1}{c|}{}
\end{tabular}

Factors Influencing Farmers Access to Formal Agricultural Credit Facilities. Table 3 presents the results of the Logistic regression used to evaluate the factors influencing access to credit among the sampled small scale crop farmers' in Gwagwalada Area Council, Abuja, Nigeria. Farm size $\left(X_{4}\right)$ had a significant and positive $(P<0.5)$ influence on small scale crop farmers' access to agricultural credit. This suggests that farmers' access to agricultural credit becomes better as their farm size increases. The implication of this is that the need for financial assistance to acquire sufficient production resources is a critical factor, which could serve as a driving force to seek for agricultural credit for expanding farm production (Asogwa et al, 2014). Membership of Co-operative $\left(X_{6}\right)$ also had a significant and positive influence $(P<0.01)$ on small scale crop farmers' access to agricultural credit. This suggests that small scale crop farmers' access to agricultural credit becomes better when they belong to a cooperative society (Hussein, 2007). It can also be inferred from this that membership of cooperative society imparts on the farmers the capacity to access credit facilities. According to Atieno (2007) cooperative societies have the capacity and legal backing to arrange for credit facilities for their members. Distance of household from source of credit $\left(\mathrm{X}_{10}\right)$ also had a significant and positive influence $(P<0.01)$ on small scale crop farmers' access to agricultural credit. This implies that small scale crop farmers' access to agricultural credit is higher when the source of credit is closer to where the farmer resides (Amaza and Maurice, 2005). Farmers are more likely to seek credit facilities if they can easily access such sources of credit (Afolabi, 2010). The Cox and Snell R square (coefficient of determination) $\left(R^{2}\right)$ was 0.504 . This indicates $50 \%$ variation in small scale crop farmers' access to agricultural credit is accounted for by variations in the selected explanatory variables, suggesting that the model has explanatory power on the changes in small scale crop farmers' access to 
agricultural credit. The Nagelkerke $R$ square (adjusted $R^{2}$ ) also supported the claim with a value of 0.710 or $71 \%$. This implies that the selected explanatory variables explain the behavior of small scale crop farmers' access to agricultural credit at $71 \%$ level of confidence. There was a significant change in -2 log-likelihood. This suggests that there was a significant cause-effect relationship between small scale crop farmers' access to agricultural credit and the selected explanatory variables. This is in line with the findings of Asogwa et al (2014).

Table 3 - Maximum Likelihood Estimates of the Logit Model

\begin{tabular}{|c|c|c|c|c|}
\hline Variable & $\boldsymbol{\beta}$ & S.E & Wald & Level of Significance \\
\hline Age $\left(X_{1}\right)$ & 0.036 & 0.073 & 0.245 & NS \\
\hline Household Size $\left(X_{2}\right)$ & -0.284 & 0.212 & 1.792 & NS \\
\hline Educational Level $\left(X_{3}\right)$ & 0.130 & 0.95 & 1.866 & NS \\
\hline Farm Size $\left(X_{4}\right)$ & $0.378^{* *}$ & 0.176 & 4.596 & 0.05 \\
\hline Farm Investement $\left(X_{5}\right)$ & 0.000 & 0.000 & 0.584 & NS \\
\hline Cooperative Member $\left(X_{6}\right)$ & $2.148^{\star * *}$ & 0.824 & 6.793 & 0.01 \\
\hline Access to Ext. Services $\left(X_{7}\right)$ & 16.731 & 12696.39 & 0.000 & NS \\
\hline Awareness of Credit $\left(X_{8}\right)$ & -0.807 & 0.864 & 0.871 & NS \\
\hline Farming Experience $\left(X_{0}\right)$ & 0.034 & 0.065 & 0.271 & NS \\
\hline Household Distance $\left(X_{10}\right)$ & $0.658^{\star * *}$ & 0.164 & 16.155 & 0.01 \\
\hline Sample Size & 100 & \multirow{5}{*}{\multicolumn{3}{|c|}{$\begin{array}{l}\text { *-Significant at } 10 \text { Percent Probabillity Level } \\
\text { **-Significant at } 5 \text { Percent Probability Level } \\
{ }^{* * *-S i g n i f i c a n t ~ a t ~} 1 \text { Percent Probability Level }\end{array}$}} \\
\hline Log Likelihood Function & $53.681^{* *}$ & & & \\
\hline Cox \& Snell R Square & 0.504 & & & \\
\hline Nagelkere R Square & 0.710 & & & \\
\hline Chi Square & $70.139^{\star * *}$ & & & \\
\hline
\end{tabular}

Major Problems Encountered in Accessing Agricultural Credit. The results presented in Table 4 shows that majority, $(50 \%)$ of the farmers faced problem of too much bank requirements as one of the constraints of accessing agricultural credit. Furthermore, twenty five percent $(25 \%)$ of the respondents faced problem of lack of collateral security as a constraint to sourcing agricultural credit, also fifteen percent (15\%) of the respondents also faced the problem of insufficient amount disbursed to them while ten percent (10\%) faced the problem of delay in disbursement of agricultural credit, this is in line with the findings of Lawal et al (2009) who stated that, the time lag between application and disbursement of credit service was indicated as the major constraints borrowers faced. This implies that too much bank requirements or procedure (administrative bureaucracy) and lack of collateral security constituted the major constraints to sourcing agricultural credit among the respondents. A study by Ekwere et al (2014) had earlier reported that long delay and administrative bureaucracy as well as lack of collateral often time affect farmers interest in accessing agricultural credit.

Table 4 - Major Problems Encountered in Accessing Agricultural Credit

\begin{tabular}{|c|c|c|}
\hline Problems Encountered & Frequency & Percentage \\
\hline Lack of Collateral & 25 & 25.00 \\
\hline Too Much Bank Requirements & 50 & 50.00 \\
\hline Delay in Disbursement of Funds & 10 & 10.00 \\
\hline Insufficient Amount Disbursed & 15 & 15.00 \\
\hline $\begin{array}{l} \\
\text { Total }\end{array}$ & 100 & 100.00 \\
\hline
\end{tabular}

Suggested Solutions to Problems Encountered while Accessing Agricultural Credit. The suggested solution to the problems encountered in accessing agricultural credit, fifty percent $(50 \%)$ of the respondents were of the opinion that formal credit institutions should reduce their requirements and procedures in order to encourage farmers to apply for formal agricultural loans. Also, twenty percent $(20 \%)$ of the respondents opined that collateral system of formal credit institutions should be reviewed so as to allow more small scale farmers have access to agricultural credit facilities. Moreso, fifteen percent (15\%) of the respondents suggested that interest rate should be reduced especially for agricultural credit so as to encourage farmers to access agricultural credit. 
Table 5 - Suggested Solutions to Problems Encountered while Accessing Agricultural Credit

\begin{tabular}{|l|c|c|}
\hline \multicolumn{1}{|c|}{ Suggested Solutions } & Frequency & Percentage \\
\hline Reduction in Bank Procedures/ Requirements & 50 & 50.00 \\
Collateral System Should be Reviewed & 20 & 20.00 \\
Reduction in Interest Rate & 15 & 15.00 \\
Timely Disbursement of Funds & 10 & 10.00 \\
Actual Amount Applied Should be Disbursed & 05 & 05.00 \\
\hline \multicolumn{1}{|c|}{ Total } & $\mathbf{1 0 0}$ & $\mathbf{1 0 0 . 0 0}$ \\
\hline
\end{tabular}

Furthermore ten percent (10\%) of the respondents advised that funds should be disbursed on time as at when needed, since farming activities is somewhat dependent on timing especially during the rainy season when most small scale farmers tend to begin farming activities. Also five percent $(5 \%)$ of the respondents suggested that the actual amount applied should be disbursed.

\section{SUMMARY OF FINDINGS}

This study examined "Access to Formal Credit Facilities among Small Scale Crop Farmers' in Gwagwalada Area Council, Abuja, Nigeria". Majority of the small scale crop farmers were male, eighty seven (87) percent and were married. Most of them were literate eighty one (81) percent. This study revealed that sixty nine (69) percent of the sampled small scale crop farmers were less than fifty (50) years of age. The study showed further that thirty one (31\%) percent of the respondents had access to formal agricultural credit. Fifty six (56\%) percent of the respondents were not members of cooperative society. Furthermore, the sources of credit among the respondents were institutional credit (formal) sources. The result of Logit regression showed that farm size, membership of co-operative and household distance from source of credit had positive and significant influence on access to formal agricultural credit among the respondents in the study area. Majority of the respondents faced one problem or the other that affected their access to formal agricultural credit. However, delay in approval and disbursement of credit, lack of collateral security as well as too much bank procedures and requirements constituted the major constraints to sourcing formal agricultural credit among the respondents in the sample area.

\section{CONCLUSION}

The role of agricultural credit in the development of agricultural sector cannot be overemphasized. Credit enhances farmers' purchasing power to enable them acquire modern technologies for their farm production. Access to formal credit seems to be limited among small scale farmers due to certain constraints. This study has identified farm size, membership of co-operative, household distance from source of credit and total amount of credit accessed as major factors influencing farmers' access to formal agricultural credit.

\section{RECOMMENDATIONS}

In order to improve small scale crop farmers' access to formal credit facilities and based on the findings of this study, the following recommendations have been proffered;

(i) Credit should be disbursed to farmers with minimum delay, since respondents identified timely disbursements of loans as a way of an effective implementation. This when done on time will enable farmers' meet their farm needs in the right season and increase their farm output.

(ii) Formal credit institutions should be widely spread, so that farmers will only travel for a short distance to access financial services, it will go a long way in encouraging the proper utilization of institutional credit by the farmers' with the view of improving their economic activities.

(iii) Efforts should be made to create more awareness about the existence of formal agricultural credit for agricultural production among small scale farmers especially in the rural 
areas. The farmers should also be enlightened on how to go about accessing agricultural credit facilities. This will enable them to obtain financial assistance that would help boost their farm investment thereby expanding production and hence increasing farm income.

(iv) Rural farmers should be encouraged to join co-operative associations as this can increase their chances of accessing formal agricultural credit facilities because of the comparative advantage associated with cooperative societies.

(v) Stringent measures coupled with loan monitoring activities should be put in place by formal credit institutions to check and reduce the incidence of agricultural credit misappropriation by beneficiaries.

\section{REFERENCES}

1. Adams, D., and Fitchett, D. (2002). Informal Finance in Low-income Countries, Westview Press, Boulder. Pp. 89.

2. ADB (2009). African Development Bank Enhancing Capacity for Youth Employment in Africa: Some Emerging Lessons, African Capacity Development Brief, 2(2): 34-70.

3. Adejobi, O. and J.T. Atobatele. (2008). An Analysis of Loan Delinquency Among SmallScale farmers in Southwestern Nigeria. Application of Logit and Loan Performance Indices, East African Agricultural and Forestry Journal 74. Pp. 2-27.

4. Afolabi, J. A., (2010). Analysis of loan Repayment of Small scale farmers in Oyo State in South - Western Nigeria. Journal of Social Science, 222:Pp. 115-119.

5. Amadi, S., Momodu, N. and Chukwu-Igwe, E.C., (2001). The Commercial and Merchant Banks Credit to the Preferred Sector of the Nigerian economy $1981-1997$. A Critical Appraisal. International Journal of Economics \& Development. 2 (1). Pp. 89-105.

6. Amaza, P.S. and Maurice, D.C (2005). Identification of Factors that Influence Technical Efficiency in Rice-Based Production Systems in Nigeria. Paper presented at Workshop on Policies and Strategies for Promoting Rice Production and Food Security in SubSaharan Africa. November 2005, Cotonou (Benin). Pp. 7-9.

7. Asogwa, B.C., Abu O. and Ochoche G.E. (2014). Analysis of Peasant Farmers' Access to Agricultural Credit in Benue State, Nigeria. British Journal of Economics, Management \& Trade. 4(10): 1525-1543.

8. Atieno, R. (2007). Determinants of Credit Demands by Smallholder Farmers in Kenya: An Empirical Analysis. Tropenlandwirt, 98, 7(11) Pp. 63-71.

9. Blackman, A. (2001). Why Don't Lenders Finance High Return Technological Changes in Developing Countries Agriculture? American Journal of Agricultural Economics, 83, Pp. 1024-1035.

10. Balogun, O. and Yusuf, S. (2011). Determinants of Demand for Microcredit among the Rural Households in South-Western States , Nigeria. Journal of Agricultural and Social sciences, 7(2), Pp. 41-48

11. Beck, T. (2007). Financing constraints of SME's in developing countries. Evidence, determinants and solutions. J. Int. Money Finance. 31(2): Pp. 401-441

12. Bolarinwa, K . K . and Oyeyinka, R. A., (2005). "Communal Conflict Impact on Agricultural Extension Agents Operation in Atisbo Local Government Area of Oyo State" Journal of Agric. Extension 8(1). Pp. 34-42.

13. Chen, K., and Chivakul, M. (2008). What Drives Household Borrowing and Credit Constraints? Evidence from Bosnia and Herzegovina (IMF Working Paper WP/08/202). Washington, DC: International Monetary Fund. Pp. 2-34.

14. Diagne, A. (1999). Determinants of Household Access and Credit Participation in Formal and Informal Credit Markets in Malawi. Discussion paper, Pp. (67).

15. Ekwere, G.E. and Edem I.D. (2014). Evaluation of Agricultural Credit Facility in Agricultural Production and Rural Development. Global Journal of Human-Social Science: Geography, Geo-Sciences, Environmental Disaster Management, 14(3): pp. 2-26.

16. Ghate, P. (1988). Informal Finance: Some Findings from Asia: Oxford University Press. Pp. 85. 
17. Ghorbani, M., Kohansal, M.R., Mansoori, H., (2005). "Effect of Credit Accessibility of Farmers on Agricultural Investment and Investigation of Policy Options in KhorasanRazavi Province, India. Journal of Applied Science. 2005;8: Pp. 4455-4459.

18. Ihimodo, R.S. (2005). The Roles of Group and Credit Cooperatives in Rural Lending. World Bank Research Observer Publication (4). Pp. 134-160.

19. Jumare, B. M., (2006). BHM 641- Financial Management in Local Government. Lagos: NOUN. Pp. 45.

20. Jemaneh, S. (2002). Financial Arrangements and Determinants of Consumption Credit use by Rural Households: The Case of Loume Woreda. Pp. 22-27.

21. Lawal J . O, Omonona B. T, Ajani O. I, Oni A. O., (2009). Effects of Social Capital on credit Access among Cocoa Farming Households in Osun State, Nigeria. Agric. Journal; 4: Pp. 184-191

22. Manyong V.M; Ikpi A; Olayemi J.K; Yusuf S.A; Omonona B.T; Okoruwa, V., and Idachaba F.S (2005). Agriculture in Nigeria: Identifying Opportunities for Increased Commercialization and Investment. IITA, Ibadan, Nigeria. Pp.. 159.

23. Martokoesoemo, S. (2004). Beyond The Frontiers of Indonesian Banking and Finance. Financial Intermediation to Mobilize the Potential of Small Entrepreneurs Institute Bankir, Indonesia. Pp. 20-42.

24. Mpuga, P. (2008). Constraints in Access to and Demand for Rural Credit: Evidence from Uganda. African Development Review, 22(1), Pp. 115-148.

25. Nwaru, JC (2004). Rural Credit Market and Resource Use in Arable Crop Production in Imo State of Nigeria, PhD Dissertation Micheal Okpara University of Agriculture, Umudike, Abia State, Nigeria. Pp. 30-45.

26. Odoemenem I, U and Osogwa, B.C., (2010). Capital Resource Use and Allocation in Cereal Crop Enterprise: Empirical Evidence from the Cereal Crop Farmers of Benue State, Nigeria. Journal of Social Science, 23(2): Pp. 91-97.

27. Okpetu, S.A. (2001). Agricultural Financing in Schools and Colleges: A Critical Survey. Conference proceeding of the East Africa Educational Development Zambia. University of Zambia Press. Pp. 22-46.

28. Okurut, N., Schoombee, A., and Van der Berg, S. (2004). Credit Demand and Credit Rationing in the Informal Financial Sector in Uganda. Paper to the DPRU/Tips /Cornell Conference on African Development and Poverty Reduction. Pp. 134-140.

29. Okwoche V.A, Asogwa B.C, Obinne P.C. (2012). Evaluation of agricultural credit utilization by cooperative farmers in Benue State. of Nigeria. European Journal of Economics, Finance and Administrative Sciences. pp 123-133.

30. Olaitan S.A. (2006). Finance for small and Medium Enterprises: Nigeria's Agricultural Credit Guaranteed Scheme Fund. Journal of International Farm Management. 3 (2) Pp. 1-9.

31. Tinh, D., John G., and Mark H., (2010). Impact of Household Credit on Education and Healthcare Spending by the Poor in Peri-Urban Areas, Vietnam. Journal of Southeast Asian Economie . 31,(24). Pp. 103-119.

32. Yaron, J. (2002). Rural Finance in Developing Countries. World Bank's Agricultural Policies Working Paper. World Bank, Washington D.C. Pp. 5-15. 